\title{
Kaasava hariduse tähendus ja tõhusa rakendamise tegurid Eesti kontekstis: õpetajaid koolitavate või nõustavate spetsialistide vaade
}

\author{
Tiina Kivirand ${ }^{\text {a1 }}$, Äli Leijen ${ }^{\text {a }}$ Liina Lepp ${ }^{\text {a }}$, Liina Malva ${ }^{a}$ \\ ${ }^{a}$ Tartu Ülikooli haridusteaduste instituut
}

\begin{abstract}
Annotatsioon
Kaasava hariduse teemalise õpetajakoolituse arendamine on aktuaalne nii Eestis kui ka rahvusvaheliselt. Õpetajate oskuste ja teadmiste kujundamisel on otsustav roll spetsialistidel, kes õpetajaid koolitavad või nõustavad. Seejuures on tähtis, et spetsialistid omaksid ühist arusaama kaasava hariduse tähendusest ning tõhusatest rakendamise viisidest. Siinse uuringu eesmärk oli välja selgitada, kuidas mõistavad õpetajaid koolitavad või nõustavad spetsialistid kaasava hariduse tähendust ja milliseid tegureid nad peavad oluliseks, et tagada kaasava hariduse tõhus rakendumine. Andmeid koguti poolstruktureeritud intervjuudega 15 spetsialistilt. Kvalitatiivse induktiivse sisuanalüüsi tulemused näitasid, et kaasavat haridust mõisteti nii hariduslike erivajadustega laste eraldi õpetamisena eriklassides ja erikoolides kui ka kõigi laste koosõppena. Võtmekomponentidena kaasava hariduse paremal rakendumisel nähti õpetajate koolituse tõhustamist, vajalike ressursside olemasolu, õpetajate toetamist ja motiveerimist ning poolte senisest suuremat koostööd.
\end{abstract}

Võtmesõnad: kaasav haridus, tähendus, rakendamise tegurid, tõhusad õpetamismeetodid

\section{Sissejuhatus}

Kaasava hariduse tähenduslik ja tõhus rakendamine on olnud viimaste aastakümnete jooksul suur proovikivi nii rahvusvaheliselt kui ka Eestis. Ühelt poolt peetakse oluliseks, et kõigile oleks tagatud võrdne õigus haridusele, teiselt poolt on fookuses ka püüdlus sotsiaalselt kaasavama ja sidusama ühiskonna loomise poole. Euroopa Eriõppe ja Kaasava Hariduse Agentuuri liikmesriigid näevad nende eesmärkide realiseerimisel võtmekomponendina kaasavate

Haridusteaduste instituut, Tartu Ülikool, Salme 1a, 50103 Tartu; tiina.kivirand@ut.ee. 
haridussüsteemide kujundamist (Agency Position ..., s.a.). Rahvusvahelised organisatsioonid, nagu UNICEF, UNESCO, ÜRO ja EN, on poliitilistes dokumentides püüdnud küll kaasava hariduse tähendust sõnastada ja anda suuniseid kaasavate koolide kujundamiseks, kuid siiski rõhutatakse paljudes uuringutes, et kaasava hariduse tähendust tõlgendatakse eri riikides väga erinevalt (Cameron, 2017; Hardy \& Woodcock, 2015). Ainscow ja Miles (2008) peavad oluliseks, et kaasava hariduse ja kaasavate koolide arendamisel on esmatähtis saavutada ühine ja selge arusaam, mida kaasav haridus tegelikult tähendab. Ometi on selle kujunemine osutunud keeruliseks. Haridussüsteemide arendamine on keerukas protsess, mis sõltub riikide geograafilisest, poliitilisest ja kultuurilisest kontekstist, millest tulenevad ka erinevad spetsiifilised väärtused ja uskumused.

Teisalt rõhutab Schuelka (2018), et edukas kaasamine on väga kompleksne protsess, mille puhul üks olulisimaid võtmekomponente on õpetajad, kes on koolitatud rakendama mitmesuguseid meetodeid kõigi laste kaasamiseks. Kaasava õpetajakoolituse arendamine on ka Euroopa tasandil seatud prioriteediks, kusjuures õppekavade väljatöötamises nähakse olulist rolli ülikoolidel ning koolitajate endi arusaamadel kaasavast haridusest ja tõhusatest õpetamise meetoditest (Allan, 2011; European Agency ..., 2015).

Eestis on kaasava hariduse põhimõte sätestatud põhikooli- ja gümnaasiumiseaduses alates 2010. aastast, mille kohaselt haridusliku erivajadusega õpilane õpib üldjuhul elukohajärgses koolis tavaklassis (Põhikooli- ja ..., 2010). Eesti Rakendusuuringute Keskuse CenTARi 2016. aastal tehtud uuring näitab, et tavakoolides õppivate hariduslike erivajadustega õpilaste arv on pärast seaduse jõustumist aastatel 2010-2014 küll suurenenud, aga suurenenud on just tavakoolide eriklassides õppivate õpilaste arv, mitte hariduslike erivajadustega õpilaste kaasatus tavaklassi (Räis, Kallaste, \& Sandre, 2016).

Kaasamist takistavate tegurite puhul tõstetakse esile eeskätt vajalike ressursside puudumist, aga ka eri sihtrühmade (koolijuhid, õpetajad, tugispetsialistid) arusaamade erinevust kaasava hariduse rakendamise võimaluste ja vajalikkuse suhtes ning õpetajate väheseid teadmisi hariduslike erivajadustega lastega töötamisel (Räis \& Sõmer, 2016). Ka teistes Eestis tehtud uuringutes rõhutatakse kaasava hariduse eduka rakendamise ühe olulisima komponendina just tõhusat õpetajakoolitust (Balti Uuringute ..., 2015; Häidkind \& Oras, 2016). Seega on ühelt poolt tarvis leida võimalusi ühiste arusaamade kujundamiseks kaasava hariduse tähendusest ning teiselt poolt on vaja arendada kaasava hariduse teemalist õpetajakoolitust. Kuna mõlema teema puhul on tähtis roll õpetajaid koolitavatel või nõustavatel spetsialistidel, keskendutaksegi siinses artiklis nende spetsialistide arusaamadele kaasavast haridusest ja teguritele, mis nende hinnangul on olulised kaasava hariduse tõhusal rakendumisel. 


\section{Kaasava hariduse tähendus ja rakendamise viisid}

Kaasava hariduse tähenduse tõlgendamise suhtes on uurijad erinevatel seisukohtadel. Mõned autorid väidavad, et ei ole ühtset ja selgelt kokkuleppelist kaasava hariduse definitsiooni ning tõlgendust (Cigman, 2007; D’Alessio \& Watkins, 2009). Haug (2017) rõhutab, et arusaamad kaasava hariduse eesmärkidest, õpetamise filosoofiast ning praktikast erinevad riigiti ja varieeruvad isegi ühe riigi eri tasanditel. Pidades silmas õppurite sihtrühma, keda kaasav haridus mõjutab, tuuakse välja kaks eri jaotust: kitsas ja lai definitsioon. Kitsas kaasava hariduse definitsioon on suunatud ainult ametlikult määratletud hariduslike erivajadustega õppuritele ja eriti just puuetega õppijate võimalustele õppida elukohajärgses koolis (Arduin, 2015; Armstrong, Armstrong, \& Spandagou, 2011). Seevastu lai definitsioon hõlmab kõiki õpilasi, sealhulgas marginaliseeritud rühmi (Thomas, 2013) ning keskendub mitmekesisusele ja sellele, kuidas koolid on valmis arvestama kõigi õpilaste erisuste ja vajadustega (Armstrong et al., 2011). Mõlema definitsiooni puhul tekitab kaasava hariduse ühtsel tõlgendusel segadust asjaolu, et jaotused on rühmitatud õpilasrühmade alusel, aga riigid käsitlevad hariduslike erivajaduste ja puuete klassifikatsioone erinevalt (D’Alessio \& Watkins, 2009; Räis et al., 2016). Siiski, levinuim kaasava hariduse käsitlus on arusaam, et kõik õpilased olenemata nende erisuste või takistuste iseloomust õpivad kodulähedases tavakoolis koos eakaaslastega, saavad seal kvaliteetset õpetust, vajalikku sekkumist ja tuge, et täita õppekava edukalt (Alquraini \& Gut, 2012). Domineeriv idee on siinkohal just demokraatlikud väärtused ja sotsiaalne õiglus ning enamik Euroopa riike püüdleb selle poole, et kaasavat haridust realiseerida just nimetatud käsitluse põhjal (Haug, 2017).

Ka Eesti hariduspoliitika kujundajad on lähtunud kaasava hariduse tõlgendamisel üldlevinud rahvusvahelistest printsiipidest, pidades silmas laia definitsiooni ja kõigi õpilaste õigust kvaliteetsele haridusele (vt nt Haridus- ja ..., s.a.), kusjuures hariduslike erivajadustega õpilaste määratluses on toimunud viimase kümnendi jooksul muutused. 2010. aasta põhikooli- ja gümnaasiumiseaduses defineeriti hariduslikku erivajadust laia spektrina, st haridusliku erivajadusega õpilaseks peeti kõiki õpilasi, kes vajasid peale klassis toimuva õppele lisatuge või teistsugust õppekorraldust (Põhikooli- ja ..., 2010). Alates 2018. aastast tehti seadusesse muudatused ning seaduse tasandil kitsendati haridusliku erivajadusega õpilase määratlust. Viimase käsitluse kohaselt on haridusliku erivajadusega need õpilased, kellele on ametlikult koolivälise nõustamismeeskonna otsusega soovitatud rakendada tõhustatud või erituge (Põhikooli- ja ..., 2018). Kui Euroopa Eriõppe ja Kaasava Hariduse Agentuuri liikmesriikide seas on kokkulepe, et ametlikult määratletud erivajadustega õpilasi loetakse kaasatuks, 
kui nad vähemalt 80\% nädalakoormusest õpivad koos erivajadusteta õpilastega ühes klassiruumis (Euroopa Eriõppe ..., 2018), siis Eesti kontekstis kaasava hariduse tõlgendamisel kõikide laste koosõppimise määra esitatud ei ole.

Kaasava hariduse rakendamise viisidest on Cigman (2007) eristanud kolme lähenemist: radikaalne, keskmine ja UNESCO lähenemine. Cigmani jaotuse põhjal tähendab radikaalne lähenemine erikoolide sulgemist ja kõigi õpilaste tavakooli paigutamist. See tähendab, et koolid peavad olema ümber korraldatud viisil, et suudaksid kõigi õppijate vajadusi rahuldada. Keskmine lähenemine aktseptib, et teatud spetsiifiliste erivajadustega ópilaste jaoks võivad erikoolid alles jääda, ja UNESCO lähenemise järgi on keskmes eeskätt kõigi õpilaste võrdne õigus haridusele.

Vaid vähestel juhtudel on suured koolisüsteemid (nt Itaalia) tulnud toime liikumisega peaaegu täieliku kaasamise mudeli poole, mis lähtub radikaalsest ja nn ühesuunalisest lähenemisest, mille kohaselt peaaegu kõik õpilased on kaasatud elukohajärgsesse tavakooli (Begeny \& Martens, 2007). Sagedamini kohandatakse aga keskmist lähenemist ja mitmesuunalist süsteemi, pakkudes nii kaasavat hariduskorraldust kui ka eraldi õpet erikoolis (Loreman, 2013). Ka Eesti püüdleb kaasavas hariduses mitmesuunalisele lähenemisele, sest seadusega on erivajadustega õppijatele loodud võimalused õppida nii tavakooli tavaklassides, tavakooli eriklassides kui ka vajaduse korral erikoolides (Põhikooli- ja ..., 2018).

Olenemata sellest, et kaasamise positiivse mõjuna on välja toodud nii kõigi õpilaste akadeemiliste saavutuste kui ka sotsiaalsete võimaluste suurenemist ning hariduslike erivajadustega õpilaste puhul ka õpingute jätkamist ja tööturule sisenemist (Kaska \& Anspal, 2016; Symeonidou, 2018), esineb probleeme kvaliteetse õpetamise tagamisel, mis on tegelikkuses nende positiivsete tulemuste eelduseks (Bešic, Baleczec, Krammer, \& Gasteiger-Klicpera, 2016). Uuringud on näidanud, et õpetajate valmisolek ja enesekindlus kaasava hariduse rakendamisel sõltub olulisel määral nende teadmistest ja oskustest korraldada õpet viisil, mis soodustaks kõikide õpilaste arengu toetamist (Boer, Pijl, \& Minnaert, 2011). Järgnevalt vaadeldaksegi, millised on levinumad kaasamist toetavad õpetamise meetodid ja kontekstuaalsed tegurid.

\section{Kaasamist toetavad õpetamise meetodid ja kontekstuaalsed tegurid}

Selleks, et kaasav hariduskorraldus tooks eduelamusi kõigile õpilastele, on oluline rakendada tõhusaid õpetamise meetodeid. Broderick, Mehta-Parek ja Reid (2005) rõhutavad, et kui õpetajad diferentseerivad õpet efektiivselt, hindavad 
pidevalt õpilaste arusaamu, õpetavad vastutustundlikult ja võimaldavad õpilastel demonstreerida nende oskusi ja teadmisi erinevatel tähenduslikel viisidel, siis suudavad kõik õpilased kaasavas klassiruumis edukalt osaleda.

Uuringud on näidanud, et üks levinumaid kaasava hariduse toetamise meetodeid on otseselt erivajadusega õpilasele suunatud diferentseeritud õpetamine, mis tähendab, et õpetamisprotsess on kohandatud õpilaste individuaalsetele võimetele (Bešic et al., 2017; Saloviita, 2018). Õpet diferentseeritakse eri viisidel. Näiteks rakendatakse spetsiifiliselt ühele õpilasele või rühmale suunatud õpet klassiruumis või väljaspool seda ning vajaduse korral kohandatakse õppe sisu ja õpitulemusi või õpikeskkonda. On aga oluline rõhutada, et õpikeskkonna diferentseerimine ei tähenda järjepidevat rühmade eraldamist - pigem on tegemist mõne üksiku tunni või ajutise ajaperioodiga (Bešic et al., 2017).

Diferentseeritud õpetamisest mõnevõrra erinev on kaasav pedagoogika (inclusive pedagogy), mille kohaselt püütakse vältida erivajadustega õpilaste marginaliseerimist ning rakendatakse meetodeid, mis on suunatud kõigile õpilastele klassiruumis (Florian \& Black-Hawkins, 2011). Kõiki õppijaid kaasavaks meetodiks peetakse eakaaslaste toetatud (peer-assisted) koosõppimist (European Agency ..., 2003), kus õpilased toetavad üksteist õpiülesannete täitmisel. Koosõppimise üheks positiivseks mõjuks hinnatakse õpilastevaheliste suhete paranemist ja erivajadustega õpilaste kõrvalejäämise riski vähendamist (Saloviita, 2018).

Kogu klassile suunatud meetoditest soovitatakse rakendada ka koosõpetamist (co-teaching), mis tähendab, et vähemalt kaks haridusspetsialisti (kaks õpetajat või õpetaja ja eripedagoog) jagavad vastutust õpetamise eest samas klassiruumis (European Agency ..., 2003). Westling Allodi (2002) tõstab esile, et kahe õpetaja olemasolu klassis võimaldab õpilaste vajadustele efektiivsemalt reageerida ja seetõttu omab positiivset mõju õpilaste akadeemilisele ja sotsiaalemotsionaalsele arengule. Lisaks sellele on leitud, et koosõpetamine tõstab ka õpetaja enesekindlust ning teadmisi, eriti juhul, kui õpetamine toimub koos eripedagoogiga (Bešic et al., 2017).

Kontekstuaalsetest teguritest kaasava hariduse tõhusal rakendamisel tõstavad Bešic jt (2017) esile eelkõige klassi koosseisu ning õpilaste arvu, mille juures peetakse silmas, et erivajadustega lapsed ei satuks kõik ühte klassi. Mida väiksem on erivajadustega laste suhtarv, seda suurem on tõenäosus, et nad õpivad teistelt ühiskondlikult vastuvõetavaid käitumisnorme ning on edukamad ka õpitulemustes. Sellest lähtuvalt peetakse vähem efektiivseks ka erivajadustega laste eraldamist üheks rühmaks. Klassi koosseisu muutmisel väärtustatakse eeskätt õpilaste arvu vähendamist, mis võimaldab õpetajal paremini oma tööd korraldada iga lapse võimetele vastavalt (Engelbrecht 
et al., 2017). Tähtis on ka tugispetsialistide rolli muutus. Peale traditsioonilise erivajadustega laste individuaalse toetamise nähakse üha enam tugispetsialistide suurenevat rolli õpetajate toetamisel, nõustamisel ja koostöisel õpetamisel (Perez, Llanos, \& Muntaner Guast, 2017). Kontekstuaalsetest teguritest rõhutatakse veel koostööd lastevanemate ja kogukonnaga, hariduspoliitika selgust ja vajalike ressursside olemasolu, aga ka õpetajate motiveeritust ning täienduskoolituse võimaluste olemasolu (Engelbrecht et al., 2017).

\section{Õpetajakoolituse osatähtsus kaasava hariduse rakendamisel}

Tõhus kaasava hariduse rakendamine on seega mitmetahuline püüdlus, mis eeldab kõikide kooliga seotud poolte kaasatust ja eeskätt motiveeritud õpetajaid, nende positiivset suhtumist kaasavasse haridusse (Kaur, Noman, \& Awang-Hashim, 2015) ja hariduslike erivajadustega õpilaste sotsiaalset aktsepteerimist (Huber, Gerullis, Gebhardt, \& Scwab, 2018). Vähem tähtsaks ei tohiks pidada ka ühtse koolikogukonna tunnetust, milles mängivad suurt rolli nii positiivne suhe õpetajate ja lastevanemate vahel kui ka õpetajate ja tugispetsialistide omavahelise koostöö võimalikkus (Engelbrecht et al., 2017). Forlin ja Sin (2017) rõhutavad, et kui õpetajad on sobivalt koolitatud, suhtuvad erinevate võimetega õpilaste kaasamisse positiivselt ning vajalikud ressursid ja tugi on kättesaadavad, siis on tõendatud palju häid kogemusi kaasava hariduse rakendamisel. Seetõttu on eriti oluline pöörata tähelepanu õpetajate reaalsest vajadusest tuleneva kvaliteetse õpetajakoolituse arendamisele. Keskenduda tuleb nii sisule, korraldusele kui ka meetoditele, et luua sobivad võimalused õpetajate professionaalsele arengule ja kaasavaks õpetajaks kujunemisele (Donelly \& Watkins, 2011). Häidkind ja Oras (2016) osutavad Eestis korraldatud uurimuses vajadusele tõhustada ka Eesti kõrgkoolides kaasava hariduse teemalist koolitust ning keskenduda just sellistele teemadele nagu kaasava hariduse sisu ja eesmärgid, erivajaduste olemus, koosõppe ja sotsiaalse kaasatuse erinevad aspektid, meeskonnatöö olulisus. Seega, õpetajakoolitust korraldavatel ülikoolidel on suur proovikivi uuendada õpetajakoolituse esma- ja täiendusõppe programme viisil, mis senisest enam toetaksid õpetajate professionaalsust kaasava õppe korraldamisel. Allan (2011) on osutanud takistavale asjaolule, et sageli ei ole õpetajakoolitajail vajalikke teadmisi kaasava hariduse olemusest ja praktikatest. Ühe olulise komponendina õpetajakoolituse arendamisel rõhutatakse ka koostöö suurendamise vajadust ülikooli õppejõudude ja õpetajaid nõustavate spetsialistide, sealhulgas koolijuhtide vahel. See eeldab, et nimetatud pooltel oleks ühtne arusaam kaasavast haridusest ja efektiivsete strateegiate rakendamisest (Allan, 2011; European Agency ..., 2015). Kuna Eesti 
kontekstis neid aspekte uuritud ei ole, seatigi uurimuse eesmärgiks välja selgitada, kuidas mõistavad õpetajaid koolitavad või nõustavad spetsialistid kaasava hariduse tähendust ja milliseid tegureid peavad nad oluliseks, et tagada kaasava hariduse tõhus rakendumine. Sõnastati järgmised uurimisküsimused.

1. Kuidas mõistavad õpetajaid koolitavad või nõustavad spetsialistid kaasava hariduse tähendust Eesti kontekstis?

2. Milliseid tegureid peavad õpetajaid koolitavad või nõustavad spetsialistid oluliseks, et tagada kaasava hariduse tõhus rakendumine?

\section{Metoodika}

\section{Valim}

Kvalitatiivse uuringu valim moodustati sihipärase valimi põhimõttel. Uuringusse kaasati 15 kaasava hariduse valdkonnas õpetajaid koolitavat või nõustavat spetsialisti Eesti eri piirkondadest, kes pidid vastama vähemalt kahele alljärgnevatest kriteeriumidest:

1) koolitusalane kogemus (nt õpetajate põhi- ja täienduskoolituse läbiviijad hariduslike erivajadustega laste toetamise ja kaasava hariduse valdkonnas);

2) kooliväline nõustamisalane kogemus (nt kohaliku omavalitsuse, maakonna või riigi tasandi nõustajad hariduslike erivajadustega laste õppe korraldamisel ja kaasavate praktikate rakendamisel);

3) koolisisene nõustamisalane kogemus (nt koolijuhid, hariduslike erivajaduste õpilaste õppe koordineerijad ja tavakoolides töötavad eripedagoogid, kes töötavad kaasavates koolides).

Uurimuses osalenute taustaandmed on esitatud tabelis 1. 
Tabel 1. Uurimuses osalenud õpetajaid koolitavate või nõustavate spetsialistide taustaandmed

\begin{tabular}{|c|c|c|c|c|}
\hline \multirow[b]{2}{*}{$\begin{array}{l}\text { Pseudo- } \\
\text { nüüm }\end{array}$} & \multirow{2}{*}{$\begin{array}{c}\text { Töökogemus } \\
\text { erivajadusega } \\
\text { lastega aastates } \\
(\mathrm{m}=22,5)\end{array}$} & \multicolumn{3}{|c|}{ Seotus valdkonnaga } \\
\hline & & $\begin{array}{l}\text { Koolitus- } \\
\text { kogemus }\end{array}$ & $\begin{array}{c}\text { Kooliväline } \\
\text { nõustamiskogemus }\end{array}$ & $\begin{array}{c}\text { Koolisisene } \\
\text { nõustamiskogemus }\end{array}$ \\
\hline S1 & 6 & & $\checkmark$ & $\checkmark$ \\
\hline S2 & 25 & $\checkmark$ & & $\checkmark$ \\
\hline S3 & 25 & $\checkmark$ & & $\checkmark$ \\
\hline S4 & 19 & & $\checkmark$ & $\checkmark$ \\
\hline S5 & 21 & & $\checkmark$ & $\checkmark$ \\
\hline S6 & 27 & & $\checkmark$ & $\checkmark$ \\
\hline S7 & 38 & $\checkmark$ & & $\checkmark$ \\
\hline S8 & 36 & $\checkmark$ & $\checkmark$ & \\
\hline S9 & 9 & $\checkmark$ & $\checkmark$ & \\
\hline S10 & 10 & $\checkmark$ & & $\checkmark$ \\
\hline S11 & 39 & $\checkmark$ & & $\checkmark$ \\
\hline S12 & 15 & & $\checkmark$ & $\checkmark$ \\
\hline S13 & 24 & $\checkmark$ & $\checkmark$ & \\
\hline S14 & 29 & $\checkmark$ & $\checkmark$ & $\checkmark$ \\
\hline S15 & 15 & $\checkmark$ & & $\checkmark$ \\
\hline
\end{tabular}

\section{Andmekogumine ja analüüs}

Siinne artikkel käsitleb kahte teemaplokki suuremamahulisest uuringust, mille andmeid koguti poolstruktureeritud intervjuudega. Intervjuu kava esimene osa keskendus kaasava hariduse tähendusele. Teises osas olid küsimused võimaluste kohta, kuidas kaasavat haridust tõhusalt rakendada. Intervjuu kava on esitatud lisas 1.

Artikli esimese autori tehtud silmast silma individuaalintervjuude alguses tutvustati intervjueeritavale töö eesmärki ja teavitati konfidentsiaalsusnõuetest, samuti paluti luba intervjuu helisalvestamiseks. Intervjuude keskmine kestus oli 50 minutit (kõige lühem 31 minutit ja kõige pikem 1 tund ja 22 minutit). Intervjuud transkribeeriti täies mahus. 
Andmeid analüüsiti kvalitatiivse induktiivse sisuanalüüsi meetodil uurimisküsimuste kaupa kvalitatiivse andmeanalüüsi veebirakenduse QCAmap (qcamap.org) keskkonnas. Uurimuse kvaliteedi tagamiseks tehti korduvkodeerimine ja kaasati kaaskodeerija esimese uurimisküsimuse analüüsijana. Nii kodeerimis- kui ka kategoriseerimisotsused arutati läbi kaasuurijatega, kuni jõuti konsensuseni. Näide kodeerimisest ja kategoriseerimisest on esitatud lisas 2.

Järgnevalt esitatakse tulemused uurimisküsimuste vastuseks tekkinud kategooriate ja alakategooriate kaupa. Tulemuste kinnitamiseks esitatakse keeleliselt toimetamata tsitaadid intervjuudest, millele on lisatud uuritava pseudonüüm.

\section{Tulemused}

\section{Kaasava hariduse tähendus}

Kaasava hariduse tähenduse selgitamisel lähtusid uurimuses osalenud õpetajaid koolitavad ja nõustavad spetsialistid ühest printsiibist: kõigil õpilastel peab olema õigus ja võimalus võimete- ning jõukohasele õppele. Erinevused ilmnesid aga nende võimaluste loomise viisides ehk õpilaste paigutuses kooli ja klassi liigiti, mille kohaselt tekkis kaks põhikategooriat: 1) õpe tavakoolis erinevate õppekorralduslike võimalustega ja 2) õpe olenemata koolitüübist.

\section{Õpe tavakoolis erinevate õppekorralduslike võimalustega}

Hariduslike erivajadustega õpilaste õpe tavakooli eriklassides

Kaasava hariduse tähendust mõtestati kontekstis, et oleks loodud ligipääs ja õppekoht elukohajärgses koolis nendele õpilastele, kes vähegi suudavad tavakoolis õppida, kuid ei peetud oluliseks, et kõik õpilased õpiksid enamiku ajast ühes klassiruumis. Nende hariduslike erivajadustega õpilaste puhul, kellele koolivälise nõustamismeeskonna poolt on soovitatud tõhustatud või eritoe rakendamist, nähti peamise võimalusena, et nad siiski õpiksid suuremas osas, eriti põhiainetes, eriklassis või erirühmas ja vaid kergemates oskusainetes võiks olla võimalus viibida koos erivajadusteta eakaaslastega.

Ma ei ole päris seda meelt, et kaasav haridus peaks olema sellises vormis esitatud, et kõik óppijad peavad ühes ruumis olema. Nendes ainetes, kus tulenevalt erivajadustest laps vajab ikkagi enam tuge ja abi, seal peaks olema võimalik kohaldada siis talle sobivaid ópivorme ja klassitüüpe. (S11)

Sellise vaatega spetsialistid pidasid tavaklassi täielikku kaasamist võimalikuks vaid kergemate erivajadustega õpilaste puhul, st kellel ei ole väga spetsiifilisi või puudest tulenevaid erivajadusi, vaid vajavad nn üldist tuge. 


\section{Hariduslike erivajadustega ópilaste ópe koos eakaaslastega tavaklassis}

Üks osa intervjueeritavatest tõlgendas kaasavat haridust kui kõigi laste koos õpetamist ühes klassiruumis, et oleks mitmekesine klass, mis looks paremad võimalused kõikide õpilaste arenguks. Samas rõhutati, et vajaduse korral tuleks erivajadustega õppijatele osutada osaajalisi tugiteenuseid individuaalselt või rühmas. Toodi välja ka asjaolu, et kaasav haridus puudutab kõiki õpilasi, mitte ainult erivajadustega õppureid, ja kaasavast hariduskorraldusest võidavad kõik, ka tavaõpilased. Rõhutati, et liialt keskendutakse erivajadustega õppijate teemale, sealjuures diagnoosimisele, ega nähta tervikpilti. Arvati, et ehk ei peakski nii palju eristama erivajadusi, sest kõigil on mingis mõttes erivajadusi ning kõigil õpilastel on õigus olla kaasatud.

Kaasav haridus minu jaoks on kõikide õpilaste jaoks, sealhulgas nõrgemate, ka tublimate ópilaste jaoks sobivate vajadusest lähtuvate õppimistingimuste loomist. Et kaasavas hariduses me arvestame, kaasame kõiki õpilasi. (S1)

Absoluutse kaasamise võimalusi ei näinud siiski ükski intervjueeritav. Eristati sügava puudega õpilasi, kelle jaoks peeti otstarbekaks korraldada õpet väikestes rühmades või klassides, aga seejuures rõhutati sotsiaalse kaasatuse tähtsust.

\section{Õpe olenemata koolitüübist}

Kaasavat haridust mõisteti ka kui lihtsalt haridussüsteemis osalemist ja võimetekohase õppe võimaluste loomist, olenemata koolitüübist. Kõige tähtsamaks peeti, et haridus oleks kõigile tagatud ja lastevanematele jäetud valikuvabadus, millisesse koolitüüpi laps paigutada.

Kõik peavadki saama erilist õpet ja kui nad kõik saavad endale vajalikku haridust, siis see ongi kaasav haridus. (S14)

Kokkuvõtvalt võib öelda, et uurimuses osalejate seas oli spetsialiste, kes mõistsid kaasava haridusena haridusliku erivajadusega õpilase võimalust õppida elukohajärgses tavakoolis, kuid õppekorralduslikult nähti erinevaid võimalusi. Spetsiifilist eripedagoogilist tuge vajavate õpilaste puhul peeti oluliseks, et põhiosa õppest oleks korraldatud eriklassides või väiksemates rühmades ning vaid kergemates õppeainetes ning ühisüritustel võiksid nad olla koos oma nn tavaeakaaslastega. Samas, üks osa intervjueeritavatest mõistis kaasava haridusena hariduslike erivajadustega õpilaste õpet tavaklassis koos eakaaslastega, pakkudes neile vajalikku tuge ja võimetekohast õpet. Kaasavat haridust tõlgendati ka kui lihtsalt ligipääsu haridusele, sealjuures õpet erikoolis. 


\section{Kaasava hariduse tõhusa rakendamise tegurid}

Kaasava hariduse tõhusate praktikate tagamisel peeti oluliseks mitmesuguseid tegureid, mis uuritavate sõnul toimivad koosmõjus. Eristus neli kategooriat: 1) koolitusvajadus, 2) ressursside olemasolu, 3) õpetajate toetamine ja motiveerimine ning 4) koostöö.

\section{Koolitusvajadus}

\section{Opetajate teadmised ja oskused}

Kaasava hariduse tõhusa rakendamise eeldusena tõsteti esile eeskätt õpetajate kompetentsuse suurendamist, et õpetajatel oleks teadmine, kuidas kaasavat haridust ellu viia. Intervjueeritavad pidasid oluliseks, et õpetajail oleks teadmised kaasava hariduse olemusest ja tähtsusest ning nüüdisaegsetest suundumustest kaasava hariduse rakendamisel. Tõsteti esile, et õpetajal ei pea olema nii spetsiifilist ettevalmistust kui eripedagoogidel, aga baasteadmisi hariduslike erivajadustega õpilaste spetsiifikast ning eripedagoogilistest oskustest peeti siiski väga oluliseks. Tähtsustati õppekava kohandamise oskust, aga ka teadmisi, kuidas diferentseerida õpet, koostada individuaalset õppekava, käitumise tugikava ja jõukohastada õppematerjale.

Õpetaja peab teadma ikkagi erivajaduste olemasolu, erivajaduste liike, põhilisi avaldumisvorme, et kuidas miski laps käitub või on või mida ta vajab selleks, et toime tulla. (S1)

Lisaks tõid uuritavad olulisena välja ka õpetajate endi suhtlemisoskusi ning oskusi kujundada õpilastevahelisi sotsiaalseid suhteid. Intervjueeritavate arvates vajaksid õpetajad kaasava hariduse kontekstis rohkem ka psühholoogiateadmisi, näiteks teadmisi tunnetusprotsesside arengust ja oskusi lapse arengut hinnata. Lisaks peeti väga oluliseks õpetajate koostööoskuste kujundamist, aja planeerimise ja eneserefleksiooni oskust, aga ka teadmisi seadustikust. Üks intervjueeritav osutas, et õpetajad peaksid kasutama õppetöö korraldamisel uurimispõhist praktikat.

\section{Oppetajat toetavate osaliste koolitus}

Õpetajate professionaalse arendamise kõrval pidasid uuritavad samaväärt oluliseks ka teiste, õpetajat toetavate osaliste koolitusvajadust. Rõhutati, et koolides rakendatavatel abiõpetajatel ja erivajadustega laste tugiisikutel puudub vajalik kompetentsus, mistõttu nad vajavad kindlasti koolitust. Tõsteti esile, et ka tugispetsialistid vajavad kaasava hariduse kontekstis ajakohastatud teadmisi ja seda just eriti valdkonnas, kuidas nõustada õpetajaid ja tagada tõhus kaasava hariduse rakendamine klassiruumi tasandil. 
Tugispetsialistid ise vajavad ka teinekord rohkem teadmisi, oskusi ja rohkem niisuguseid kaasajastatud teemale lähenemisi, et siis nad omakorda saavad ju nõustada õpetajaid. (S12)

Oluliseks sihtrühmaks, kes samuti vajab kaasava hariduse teemalist koolitust, peeti kooli juhtkonda. Rõhutati, et kaasava koolikultuuri kujundamine, mõistliku töökorralduse olemasolu, meeskonna juhtimine ja ressursside jaotus on eeskätt kooli juhtkonna ülesanne ning seetõttu on asjakohane kompetentsus koolijuhtidel väga oluline.

Laste arengu toetamisel tähtsustati lapsevanema rolli ning nähti vajadust ka lapsevanemate koolitamise järele. Toodi välja, et oluline on koolitada nii erivajadustega kui ka erivajadusteta laste vanemaid, et kujundada kaasava hariduse suhtes positiivseid hoiakuid.

\section{Erinevad koolitusvõimalused}

Intervjueeritavad pidasid oluliseks koolitusvõimaluste paljusust. Tööd alustavate õpetajate puhul rõhutati eeskätt õpetajakoolituses saadud teadmisi. Samavõrra tähtsaks peeti ka võimalusi osaleda täienduskoolitusel. Avaldati arvamust, et ülikoolides tuleks välja arendada pikaajaline ja süsteemne kaasava hariduse teemaline täienduskoolitus. Samas rõhutati ka kooli või kohaliku omavalitsuse tasandil korraldatavate vajaduspõhiste koolitusvõimaluste kättesaadavust, mis oleksid aja- ja asjakohased ning praktikaga tihedalt seostatud.

Et täiendõpe oleks ikkagi asjakohane ja õpetaks just seda, mis mul parasjagu vaja on, neid oskusi ja teadmisi ja et need lähtuksid ikkagi reaalsest elust ja praktikast, mitte ei oleks teoreetilised, ma ei tea ... kirjandusel põhinev, vaid natuke ka ikkagi Eesti oludest lähtuv. (S1)

Täienduskoolituse korraldamisel rõhutasid uuritavad veel asjaolu, et see peaks olema üles ehitatud personaalõppepõhiselt. Esmalt tuleks välja selgitada õpetaja oskusteave, millega ta praktilises töös hakkama ei saa, ning personaalsete vajaduste põhjal koostada terviklik täienduskoolituse õppekava, mis vastab õpetajate tegelikele ootustele.

\section{Ressursside olemasolu}

Kaasava hariduse tõhusa rakendamise eelduseks peeti ka vajalike ressursside olemasolu. Tõsteti esile, et oluline faktor on inimressurss, sest kaasava hariduse rakendamine vajab suuremat inimressurssi ja selle õiget paigutust. Arutleti selle üle, et praegu on Eestis puudus tugispetsialistidest ja seda just maapiirkondades. Ka tugiisikute ja abiõpetajate rakendamist peeti väga tähtsaks, 
aga osutati, et seda ei ole veel hästi ja süsteemselt kõikides koolides juurutatud. Põhjuseks nii reguleerimatus seaduse tasemel kui ka sobiva personali leidmine. Keerulisemate klassikomplektide puhul tähtsustati kahe õpetaja rakendamist klassiruumis.

Et olekski nagu reaalselt kaks õpetajat seal. ... Et koolidel oleks see võimalus igas klassiruumis mitu õpetajat, pädevustega õpetajat kindlasti. (S3)

Õpikeskkonda puudutavate ressursside puhul nimetati ruumipuudust, sest kaasav hariduskorraldus nõuab teraapiateks või rühmatöö võimalusteks lisaruume. Õppematerjalide ja õppevahendite kättesaadavuse suhtes oldi kahetisel arvamusel. Osa intervjueeritavatest arvas, et alternatiivsetest õppevahenditest on suur puudus, aga oldi ka arvamusel, et õppematerjalide ja digilahenduste võimalused aina suurenevad ning selles vallas on olukord juba päris hea. Ühe õpikeskkonda puudutava takistusena nähti ka liiga suurt õpilaste arvu klassis ning arvati, et kaasava klassi puhul peaks väiksem õpilaste arv klassis olema seadustega reguleeritud.

Et minu jaoks need grupid võibolla peaksid olema natukene väiksemad, et ópetaja tõesti jõuaks, jõuaks nagu iga lapseni, nii nagu vaja on. (S3)

Kaasava hariduse tõhusa rakendamise üheks võtmeteguriks peeti ka õpetajate ajalist ressurssi, sest sageli vajavad erivajadustega õpilased individuaalset juhendamist väljaspool tunde ning diferentseeritud õpetamine nõuab tundide ettevalmistamisel lisaaega. Seetõttu leiti, et kaasava hariduse eduka rakendamise eelduseks on õpetajate väiksem tunnikoormus.

Et õpetajal oleks aega planeerida, et oleks aega läbi mõelda, et oleks aega koostööd teha, et oleks aega ja mitte kiirustada mingisuguse programmi nimel, vaid lapse arengu nimel. (S14)

Oluliseks peeti ka ressursside õiget kasutamist. Toodi näiteid, et õpetajad, kel on vaba tund või väiksem koormus, võiksid käia toeks nendes klassides, kus on raskemaid erivajadustega õpilasi. Arvati, et ka tugispetsialistide rolli tuleks muuta viisil, et lisaks erivajadustega laste individuaalsele abistamisele toetaksid nad senisest enam just õpetajaid kaasavas klassiruumis toime tulema.

Natuke on minu arvates aegunud see variant, et meil on eraldi ópiabi tunnid. Võtame lapsed tavatundidest ära ja korjame nad kuuesesse rühma kokku ópiabi tundi. Et ma arvan, et jätkusuutlikum oleks, kui näiteks tugispetsialist käiks klassitunnis ja aitaks seal ja samal ajal annaks peale tundi õpetajale tagasisidet ja nõustaks, kuidas ta ise saaks toetada. (S1) 


\section{Õpetajate toetamine ja motiveerimine}

Intervjueeritavad rõhutasid, et hariduslike erivajadustega õpilaste tavaklassi kaasamise korral vajab õpetaja erinevatelt osalistelt toetust ja abi, et edukalt toime tulla.

Väga oluliseks peeti kooli juhtkonna suhtumist kaasavasse haridusse ja selle rakendamise võimalustesse. Arutleti, et eeskätt on juhtkond see, kes peab tahtma, soodustama ja toetama kaasava hariduse rakendamist. Juhtkonna rolli nähti nii toetava meeskonna loomisel kooli tasandil, sobiva töökorralduse organiseerimisel ning õpetajate motiveerimisel kui ka õpetajate suunamisel kaasava hariduse rakendamiseks vajaliku kompetentsuse omandamiseks.

Õpetajate toetamisel osutati ka õpetajate personaalse nõustamise vajalikkusele nii kooli kui ka koolivälisel tasandil. Kooli tasandil nähti olulist rolli tugispetsialistidel, kes oleksid orienteeritud eeskätt õpetajaid nõustama ja metoodiliselt juhendama. Õpetajate puhul, kes puutuvad hariduslike erivajadustega õpilaste kaasamisega kokku esimest korda, peeti oluliseks koolides mentorluse süsteemi juurutamist. Kooliväliste ekspertidena õpetajate personaalsel nõustamisel nähti eeskätt piirkondlike nõustamiskeskuste spetsialiste, kes vajaduse korral tuleksid kooli ja aitaksid keerulistele olukordadele kõrvalseisja pilguga lahendusi leida. Samuti arvasid intervjueeritavad, et õpetajad vajaksid supervisiooni võimalusi, vältimaks läbipõlemist ja suurendamaks nende professionaalsust. Kaasava hariduse tõhusa rakendamise ühe olulise komponendina nähti ka õpetajate motiveerimist lisapuhkusega ja senisest suuremat tunnustamist nii riigi, kohaliku omavalitsuse kui ka kooli tasandil.

Võiks rohkem tunnustada just neid õpetajaid, kes kaasava hariduse valdkonnas hästi toimetavad ja hästi toime tulevad, see on hästi oluline. (S11)

\section{Koostöö}

Koolitusvajaduse, ressursside olemasolu, õpetajate toetamise ja motiveerimise kõrval peeti kaasava hariduse tõhusa rakendamise komponendiks ka koostööd. Koolisisese koostöö puhul tähtsustati eelkõige õpetajate endi koostööd, aga ka õpetajate võrdset koostöösuhet tugispetsialistidega. Ühe võimalusena koostööd parendada nähti kovisiooni süsteemi rakendamist kooli tasandil.

Ma ikkagi leian, et väga vajalik oleks kovisiooni rühmade tekitamine koolides. Et see kovisioon tuleks nagu õpetajate tasemel ja et seal siis tuleks välja see omavaheline kogemuste jagamine. (S11) 
Oluliseks peeti ka koostööd lapsevanemate ning kooliväliste organisatsioonidega. Rõhutati, et koolid peavad tõhustama koostööd lapsevanematega ja leidma selleks eri viise, et ka lapsevanemad oleksid motiveeritud kooliga suhtlema ning see koostöö lähtuks lapse arengust ja huvidest.

Ma arvan, et kõige-kõige olulisem kaasava hariduse rakendamisel on koostöö. Et see ei saa olla midagi, mida ainult kool teeb. See ei saa olla midagi, mida ainult riik teeb, vaid me kõik peame selle nimel pingutama, sh ka ülikoolid, sh ka kohalikud omavalitsused, võibolla ka mingid MTÜd, kes iganes. (S1)

Seega võib öelda, et kaasava hariduse tõhusat rakendamist klassiruumis nähti Eesti kontekstis kompleksse teemana, mis sõltub mitme asjaolu koosmõjust. Intervjuu tulemuste põhjal võib öelda, et ühe määrava komponendina eristus nii õpetajate kui ka õpetajat toetavate osaliste koolitusvajadus, misjuures olulisimaks peeti õpetajate eripedagoogilist kompetentsust. Intervjueeritavate arvates peaks tähelepanu pöörama nii õpetajate baaskoolitusele kui ka võimaldama mitmesugust täienduskoolitust. Ühelt poolt peeti oluliseks, et ülikoolid töötaksid välja pikaajalised süsteemsed täienduskoolituse programmid, mis tagaksid õpetajate igakülgse ettevalmistuse kaasava hariduse rakendamiseks, teiselt poolt nähti vajadust ka koolituste kohandamiseks õpetajate individuaalsete vajaduste järgi.

Peale koolitusvajaduse rõhutati vajalike ressursside olemasolu koolides. Õpikeskkonda puudutavate ressursse puudutavas kerkis esile vajalike ruumide olemasolu ning õppevara ja õppevahendite kättesaadavus. Osutati ka õpetajate ajalisele ressursile ning vajadusele vähendada nende õpetajate tundide koormust, kes õpetavad kaasavates klassiruumides. Kaasava hariduse tõhusa rakendamise eeldustena nähti ka õpetajate toetamise ja motiveerimise vajadust ning osaliste ja tasandite koostööd.

\section{Arutelu}

Siinse uuringu eesmärk oli välja selgitada, kuidas mõistavad õpetajaid koolitavad või nõustavad spetsialistid kaasava hariduse tähendust ja milliseid tegureid nad peavad oluliseks, et tagada kaasava hariduse tõhus rakendumine Eesti kontekstis. Tulemused näitasid, et nii nagu Häidkindi ja Orase (2016) õpetajate ja haridusasutuste juhtide seas tehtud uuringus, tõlgendasid kaasava hariduse tähendust erinevalt ka siinses uurimuses osalenud spetsialistid.

Valdavalt mõisteti kaasava haridusena haridusliku erivajadusega õpilase võimalust õppida elukohajärgses tavakoolis, kuid õppekorralduslikult nähti erinevaid võimalusi. Üks osa intervjueeritavatest pidas kõigi laste koosõpet 
võimalikuks ainult kergemate, nn üldist tuge vajavate laste puhul, aga spetsiifilist eripedagoogilist tuge (tõhustatud ja eritugi) vajavate õpilaste puhul peeti oluliseks, et põhiosa õppest toimuks eriklassides või väiksemates erirühmades. Olenemata sellest, et haridusliku erivajadusega õpilase määratluses Eestis on alates 2018. aastast seaduse tasandil silmas peetud kitsast definitsiooni, st sihtrühmana on käsitletud õpilasi, kellele kooliväline nõustamismeeskond on soovitanud rakendada tõhustatud või erituge (Põhikooli- ja ..., 2018), lähtusid eespool kirjeldatud vaatega intervjueeritavad kaasava hariduse mõiste sisu ja rakendamisviiside kirjeldamisel laiast definitsioonist, st sihtrühmana peeti silmas kõiki tuge vajavaid õpilasi. Põhjuseks võib olla asjaolu, et haridusliku erivajadusega õpilase definitsioon on Eestis viimase kümne aasta jooksul muutunud ning kaasava hariduse kontekstis on siiani jäänud domineerima laiem erivajaduste käsitlus. Seega, kaasava hariduse tähenduse tõlgendamisel lähtusid uuritavad kõikidest haridusest kõrvalejäämise ohus olevatest õpilastest, kuid kodulähedases koolis õpet koos eakaaslastega tavaklassis pidas osa intervjueeritavaid võimalikuks vaid nende õpilaste puhul, kellel ei ole spetsiifilist puudest tulenevat erivajadust.

Siiski, kaasava haridusena mõisteti ka Euroopa Eriõppe ja Kaasava Hariduse Agentuuri liikmesriikide seas kokkulepitud kaasava õppekorralduse käsitlust, kus üldjuhul koolivälise nõustamismeeskonna ametlikult määratletud hariduslike erivajadustega õpilased enamiku õppeajast õpivad tavaklassis koos eakaaslastega, võimaldades neile sealjuures vajalikku tuge ja võimetekohast õpet. Sellise lähenemisega intervjueeritavad lähtusid enimlevinud rahvusvahelistest kokkulepetest ning definitsioonidest, mis kaasava haridusena näevad kõikide õpilaste õpet tavakoolis eakaaslastega ühes klassiruumis (vt nt Alquraini \& Gut, 2012; Haug, 2017). Samas rõhutati, et väga raske puudega õpilaste puhul võib siiski osutuda vajalikuks korraldada õpet eriklassides.

Mõned uuritavad aga käsitlesid kaasavat haridust kui lihtsalt ligipääsu haridusele, sealjuures õpet erikoolis. Sellist lähenemist mõjutab kindlasti Eestis kehtiv seadustik, mis võimaldab nn mitmesuunalist kaasava hariduse rakendamist, st ametlikult määratletud hariduslike erivajadustega õpilastele nähakse ette nii kaasavat õpet tavaklassis kui ka segregeerivat õpet eriklassis või erikoolis (Põhikooli- ja ..., 2018). Uuringu tulemused viitavad vajadusele ühtlustada õpetajaid koolitatavate ja nõustavate spetsialistide arusaamu kaasava hariduse tähendusest, et oleks võimalik õpetajaid ühtse visiooni järgi toetada ning tagada kaasava hariduse tõhus rakendamine tavakooli tavaklassi tingimustes.

Kaasava hariduse tõhusat rakendamist klassiruumis nähti kompleksse teemana, mis sõltub paljude asjaolude koosmõjust, nagu koolijuhtimine, ressursside olemasolu ja õige jaotamine, koolitatud õpetajad. Nimetatud aspektidele viitavad nii Eestis kui ka mujal tehtud uuringud (Kallaste, 2016; Schuelka, 
2018). Intervjuude tulemuste põhjal võib öelda, et ühe määrava tegurina eristuski nii õpetajate kui ka õpetajat toetavate osaliste (tugispetsialistid, koolijuhid, abiõpetajad, tugiisikud, lapsevanemad) koolitusvajadus. Kuigi tõsteti esile õpetajate teadmisi kaasavast haridusest ja selle praegusaja suundumustest, peeti esmatähtsaks siiski õpetajate eripedagoogilist kompetentsust, mis on suunatud eeskätt erivajadustega õpilaste individuaalsele toetamisele. Enam nimetati õppe diferentseerimise, õppematerjalide kohandamise, individuaalse õppekava koostamise oskusi, mis on ka Saloviita (2018) ning Bešiki jt (2016) uurimuste põhjal levinumad kaasava hariduse toetamise meetodid.

Kuigi mitmes uuringus rõhutatakse, et õpetajad peavad oskama rakendada mitut kaasavas klassiruumis kasutatavat tõendatud strateegiat, näiteks koosõppimist (peer-assisted) (European Agency ..., 2003; Saloviita, 2018), osutasid siinses uuringus osalenud intervjueeritavad kaasava klassiruumi strateegiatele vähem. Kuna kõigi õpilaste koos õpetamise positiivset mõju nii hariduslike erivajadustega kui ka erivajadusteta õppuritele on uuringute ja metanalüüsidega tõendatud (Symeonidou, 2018), tuleks ka Eesti kontekstis neid teemasid õpetajakoolituses käsitleda.

Intervjueeritavate arvates peaks Eesti kontekstis senisest enam panustama nii õpetajakoolituse tõhustamisele kui ka täienduskoolituse eri viiside võimaldamisele. Peeti oluliseks, et ülikoolid töötaksid välja pikaajalised süsteemsed täienduskoolituse programmid, mis tagaksid õpetajate igakülgse ettevalmistuse kaasava hariduse rakendamiseks. Rõhutati, et täienduskoolituse õppekavade väljatöötamisel peaks arvestama õpetajate personaalseid vajadusi ja seostatust praktikaga. Seega, kaasava hariduse teemaline õpetajakoolituse arendustegevus on Eesti jaoks oluline ülesanne. Ajakohaste koolituskavade väljatöötamine ja rakendamine eeldab ka koolitajate endi professionaalset arengut, sealhulgas ühtlustatud arusaama kaasava hariduse sisust ning tõhusatest kaasava klassiruumi praktikatest. Õpetajakoolituse õppekavade väljatöötamisel tuleks keskenduda koostööle koolidega ning üheskoos hinnata koolituste efektiivsust kaasava hariduse senisest tõhusamaks rakendamiseks.

Lisaks osaliste koolitusvajadusele rõhutati vajalike ressursside, sealhulgas inimressursi (tugispetsialistid, abiõpetajad, tugiisikud) olemasolu koolides. Õpikeskkonda puudutavate ressursside juures kerkis esile vajalike ruumide olemasolu, õpilaste väiksem arv klassis ning õppevara ja õppevahendite kättesaadavus. Osutati ka õpetajate ajalisele ressursile ja vajadusele vähendada nende õpetajate tunnikoormust, kes õpetavad kaasavates klassiruumides. Ka Engelbrecht jt (2017) tõstavad esile, et kaasavate praktikate rakendamisel on võtmeroll vajalike ressursside olemasolul. Kuigi riik on viimastel aastatel eraldanud kaasavatele koolidele täiendavaid sihtotstarbelisi finantsvahendeid hariduslike erivajadustega õppijate õppekorralduseks ja ruumipuuduse 
leevendamiseks, tuleks nii riigi, kohaliku omavalitsuse kui ka kooli tasandil senisest enam pöörata tähelepanu, kuidas olemasolevaid ressursse efektiivsemalt kasutada eeskätt kaasavama haridussüsteemi kujundamiseks. See aga eeldab eri tasandite koostööd, et kaardistada ning jagada ressursside tõhusamaks kasutamiseks hästi toimivaid praktikaid.

Kaasava hariduse tõhusal rakendamisel peeti oluliseks õpetajate toetamist ja motiveerimist, millele osutavad oma uurimuses ka Kaur jt (2015), ning osaliste ja tasandite koostööd, mida rõhutavad samuti Engelbrecht jt (2017). Õpetajate esmased toetajad on kooli juhtkond ja kogu kooli meeskond, mis eeldab kooli tasandil kaasava koolikultuuri kujundamist. See on kahtlemata valdkond, millele koolijuhtide ja õpetajate täienduskoolituses tähelepanu pöörata. Riigi ja kohaliku omavalitsuse tasandil peab aga olema tagatud süsteemne, vajaduspõhine ning just kaasavat hariduskorraldust toetav nõustamistugi. Niisuguse oskusteabe suurendamisel on oluline roll ka ülikoolidel, kus arendatakse välja ning katsetatakse koostöös haridusasutustega nüüdisaegsetel teaduspõhistel uuringutel põhinevaid koolitus- ja nõustamispakette.

Kokkuvõtteks saab öelda, et kaasava õpetajakoolituse edendamiseks Eestis tuleb eeskätt keskenduda koolitajate ja nõustajate ühtse arusaama kujundamisele kaasava hariduse mõistest, koolitajate endi professionaalsele arengule ning sealt edasi teadmiste levitamisele tõhusatest praktikatest, mis eeldab senisest suuremat teaduspõhist koostööd nii koolitajate kui ka ülikoolide vahel. Teine suur ülesanne on teaduspõhistele uuringutele tuginevate ja õpetajate vajadusest lähtuva põhi- ja täienduskoolituse õppekavade väljatöötamine.

Siinse uuringu kitsaskohana võib välja tuua asjaolu, et valimi suurus ei võimaldanud eristada erinevate kogemustega ja eri tasanditel töötavate õpetajaid koolitavate või nõustavate spetsialistide arusaamu kaasava hariduse tähendusest ning kaasava hariduse tõhusa rakendamise komponentidest, mistõttu edaspidi võiks uurida, kas ja kuidas erinevad koolitajate ning eri tasanditel töötavate õpetajaid nõustavate spetsialistide arusaamad kaasavast haridusest ja selle rakendamise võimalustest. Saadud tulemused on siiski väärtuslikud, näidates vajadusele ühtlustada arusaamu kaasava hariduse olemusest õpetajakoolitajate ja nõustajate seas ning arendada tõenduspõhist kaasava hariduse teemalist õpetajakoolitust.

\section{Tänusõnad}

Uurimus on valminud Norra ja EMP finantsmehhanismide rahastatud eeldefineeritud projekti „Kaasava hariduse õppekava ja õppe kvaliteedi arendamine ning tõhustamine“ toel. Täname intervjuudes osalenud spetsialiste. 


\section{Kasutatud kirjandus}

Agency Position on Inclusive Education Systems. (s.a.). Külastatud aadressil https://www.european-agency.org/sites/default/files/PositionPaper-EN.pdf.

Ainscow, M., \& Miles, S. (2008). Making Education for All Inclusive: where next? Prospects, 38(1), 15-34. https://doi.org.10.1007/s11125-008-0

Allan, J. (2011). Responsibly Competent: teaching, ethics and diversity. Policy Futures in Education, 9(1), 130-137. https://doi.org/10.2304\%2Fpfie.2011.9.1.130

Alquraini, T., \& Gut, D. (2012). Critical Components of Successful Inclusion of Students with Severe Disabilities: Literature Review. International Journal of Special Education, 27(1), 42-59.

Arduin, S. (2015). A Review of the Values that Underpin the Structure of an Education System and Its Approach to Disability and Inclusion. Oxford Review of Education 41(1), 105-121. https://doi.org/10.1080/03054985.2015.1006614

Armstrong, D., Armstrong, A. C., \& Spandagou, I. (2011). Inclusion: by choice or by chance? International Journal of Inclusive Education, 15, 29-39. https://doi.org/10.1080/13603116.2010.496192

Balti Uuringute Instituut (2015). Uuring „Õpetajate täiendusõppe vajadused“. Lópparuanne. Külastatud aadressil https://www.ibs.ee/wp-content/uploads/ \%C3\%95petajate-t\%C3\%A4iendus\%C3\%B5ppe-vajadused-uuringuaruanne.pdf

Begeny, J. C., \& Martens, B. K. (2007). Inclusionary education in Italy: A literature review and call for more empirical research. Remedial and Special Education 28(2), 80-94. https://doi.org/10.1177/07419325070280020701

Bešic, E., Paleczek, L., Krammer, M., \& Gasteiger-Klicpera, B. (2017). Inclusive practices at the teacher and class level: the experts' view. European Journal of Inclusive Education, 32(3), 329-345. https://doi.org/10.1080/08856257.2016.1240339

Boer, A., Pijl, S., \& Minnaert, A. (2011). Regular primary schoolteachers' attitudes towards inclusive education: a review of the literature. International Journal of Inclusive Education, 15(3), 331-353. https://doi.org/10.1080/13603110903030089

Broderick, A., Mehta-Parekh, H., \& Reid, D. K. (2005). Differentiating Instruction for Disabled Students in Inclusive Classrooms. Theory Into Practice, 44(3), 194-202. https://doi.org/10.1207/s15430421tip4403_3

Cameron, D. L. (2017). Teacher preparation for inclusion in Norway: a study of beliefs, skills, and intended practices. International Journal of Inclusive education 21(10), 1028-1044. https://doi.org/10.1080/13603116.2017.1326177

Cigman, R. (2007). A Question of Universality: Inclusive Education and the Principle of Respect. Journal of Philosophy of Education, 41(4), 775-793. https://doi.org/10.1111/j.1467-9752.2007.00577.x

D’Alessio, S., \& Watkins, A. (2009). International Comparisons of Inclusive Policy and Practice: Are We Talking about the Same Thing? Research in Comparative and International Education, 4, 233-249. https://doi.org/10.2304/rcie.2009.4.3.233

Donelly, V., \& Watkins, A. (2011). Teacher Education for inclusion across Europe. Külastatud aadressil http://www.inshea.fr/sites/default/files/www/sites/default/ files/downloads/fichiers-fiche-produits/Nras55_Donnelly_GB.pdf

Engelbrecht, P., Savolainen, H., Nel, M., \& Okkolin, M-A. (2017). Making meaning of inclusive education: classroom practices in Finnish and South African classrooms. Compare: A Journal of Comparative and International Education, 44(5), 194-202. https://doi.org/10.1080/03057925.2016.1266927 
European Agency for Development in Special Needs Education (2003). Special Needs Education in Europe. A Thematic Publication by EADSNE. Brussels. Külastatud aadressil www.european-agency.org

European Agency for Special Needs and Inclusive Education (2015). Empowering Teachers to Promote Inclusive Education. Literature review. Külastatud aadressil https://www.european-agency.org

Euroopa Eriõppe ja Kaasava Hariduse Agentuur (2018). Euroopa Agentuuri kaasava hariduse statistika. Põhipunktid ja peamised järeldused (2014/16). Külastatud aadressil https://www.european-agency.org/Eesti\%20keel/publications

Florian, L., \& Black-Hawkins, K. (2011). Exploring inclusive pedagogy. British Educational Research Journal, 37(5), 813-828. https://doi.org/10.1080/01411926.2010.501096

Forlin, C., \& Sin, K-F. (2017). In-Service Teacher Training for Inclusion. Oxford Research Encyclopedia of Education. https://doi.org:10.1093/acrefore/9780190264093.013.161

Hardy, I., \& Woodcock, S. (2015). Inclusive Education Policies: Discourses of Difference, Diversity and Deficit. International Journal of Inclusive Education, 19(2), 141-164. https://doi.org/10.1080/13603116.2014.908965

Haridus- ja Teadusministeerium (2019). Külastatud aadressil https://www.hm.ee/et/hariduslike-erivajadusega-opilaste-toetamine

Haug, P. (2017). Understanding inclusive education: ideals and reality. Scandinavian Journal of Disability Research, 19(3), 206-217. http://doi.org/10.1080/15017419.2016.1224778

Huber, C., Gerullis, A., Gebhart, M., \& Schwab, S. (2018). The impact of social referencing on social acceptance of children with disabilities and migrant background: an experimental study in primary school settings. European Journal of Special Needs Education, 33(2), 269-285. https://doi.org/10.1080/08856257.2018.1424778

Häidkind, P., \& Oras, K. (2016). Kaasava hariduse mõiste ning õpetaja ees seisvad ülesanded lasteaedades ja esimeses kooliastmes. Eesti Haridusteaduste Ajakiri, 4(2), 60-88. https://doi.org/10.12697/eha.2016.4.2.04

Kallaste, E. (2016). Haridusliku erivajadusega õpilaste kaasava hariduskorralduse ja sellega seotud meetmete tõhusus. Temaatiline raport: Statistiline ülevaade HEV levikust, kaasamisest ja tugimeetmete kasutamisest Eestis 2010-2014. Eesti Rakendusuuringute Keskus CENTAR.

Kaska, M., \& Anspal, S. (2016). Haridusliku erivajadusega õpilaste kaasava hariduskorralduse ja sellega seotud meetmete tõhusus. Temaatiline raport: Kaasamise tulemuslikkus. Eesti Rakendusuuringute Keskus CENTAR.

Kaur, A., Noman, M., \& Awang-Hashim, R. (2015). Exploring strategies of teaching and classroom practices in response to challenges of inclusion in a Thai school: a case study. International Journal of Inclusive Education, 20(5), 474-485. https://doi.org/10.1080/13603116.2015.1090489

Loreman, T. (2013). Measuring inclusive education outcomes in Alberta, Canada. International Journal of Inclusive Education, 18(5), 459-483. https://doi.org/10.1080/13603116.2013.788223

Perez, J. S., Llanos, M. N., \& Muntaner Guasp, J. J. (2017). Inclusive practices: the role of support teacher. Aula Abierta 46, 49-56.

https://doi.org/10.17811/rifie.46.2017.49-56 
Põhikooli ja gümnaasiumiseadus (2010). Riigi Teataja I 2010, 41, 240. Külastatud aadressil https://www.riigiteataja.ee/akt/13332410

Põhikooli ja gümnaasiumiseadus (2018). Riigi Teataja I 2018, 3. Külastatud aadressil https://www.riigiteataja.ee/akt/122012018003

Räis, M-L., Kallaste, M., \& Sandre, S-L. (2016). Haridusliku erivajadusega õpilaste kaasava hariduskorralduse ja sellega seotud meetmete tõhusus. Lóppraport. Eesti Rakendusuuringute Keskus CENTAR.

Räis, M-L., \& Sõmer, M. (2016). Haridusliku erivajadusega õpilaste kaasava hariduskorralduse ja sellega seotud meetmete tõhusus. Temaatiline raport: kaasamise tähenduslikkus. Eesti Rakendusuuringute Keskus CENTAR.

Saloviita, T. (2018). How common are inclusive educational practices among Finnish teachers? International Journal of Inclusive Education, 22(5), 560-575. https://doi.org/10.1080/13603116.2017.1390001

Schuelka, M. J. (2018). Implementing inclusive education. Knowledge, evidence and learning environment. Külastatud aadressil https://assets.publishing.service.gov.uk/ media/5c6eb77340f0b647b214c599/374_Implementing_Inclusive_Education.pdf

Symeonidou, S. (Toim). (2018). Kaasava hariduse ja sotsiaalse kaasatuse vahelise seose tõendus. Lõplik kokkuvõttev raport. Külastatud aadressil https://www.european-agency.org/sites/default/files/evidence_final_summary_et.pdf

Thomas, G. (2013). A Review of Thinking and Research about Inclusive Education Policy, with Suggestions for a New Kind of Inclusive Thinking. British Educational Research Journal 39(3), 473-490. https://doi.org/10.1080/01411926.2011.652070

Westling Allodi, M. (2002). A Two-level Analysis of Classroom Climate in Relation to Social Context, Group Composition and Organization of Special Support. Learning Environments Research, 5(3), 253-274.

https://doi.org/10.1023/A:1021972206111 


\title{
The meaning of inclusive education and factors for effective implementation in the Estonian context: a view of specialists who train or advise teachers
}

\author{
Tiina Kivirand ${ }^{\text {al }}$, Äli Leijen ${ }^{a}$, Liina Leppa ${ }^{a}$ Liina Malva ${ }^{a}$ \\ ${ }^{a}$ Institute of Education, University of Tartu
}

\section{Summary}

\section{Introduction}

Significant and effective implementation of inclusive education has been a major challenge both internationally and in Estonia in recent decades. The principle of inclusive education has been established at the legislative level in Estonia since 2010 (Põhikooli- ja ..., 2010). According to statistics, the number of pupils with special educational needs in mainstream schools has increased since the Act came into force, however, with that the number of students enrolled in special classes in mainstream schools has also increased (Räis, Kallaste, \& Sandre, 2016). A study conducted in Estonia showed that the meaning of inclusive education is understood differently by teachers and leaders of educational institutions (Häidkind \& Oras, 2016). Ainscow and Miles (2008) consider a common and clear understanding of what inclusive education really means as essential for the development of inclusive education systems. However, its development has proved to be difficult. On the one hand, the development of education systems is a very complex process that depends on the geographical, political and cultural contexts of countries, which in turn leads to different values and beliefs (Ainscow \& Miles, 2008). On the other hand, successful inclusion is a very complex process where one of the most important key components is identified by teachers who are trained to apply different methods to include all children (Schuelka, 2018). While the positive effects of inclusion are well known and proven (Symeondou, 2018)), there are problems in providing quality teaching that in practice could result in these positive outcomes (Bešic, Baleczec, Krammer \& Gasteiger-Klicpera, 2016). It is therefore particularly important to pay attention to developing quality teacher training that is based on the real needs of teachers (Donelly \&

Institute of Education, University of Tartu, Salme 1a, Tartu 50103 Estonia; tiina.kivirand@ut.ee 
Watkins, 2011). This requires a common understanding of inclusive education and the implementation of effective strategies by both teacher educators and other professionals who advise teachers or practice inclusive education (Allan, 2011; European Agency ..., 2015). As the aforementioned aspects have not been studied in the Estonian context and the development of pre-service and in-service teacher education in inclusive education is a relatively new challenge, this study sought answers to the following questions:

1. How do specialists who train or advise teachers understand inclusive education in the Estonian context?

2. Which factors are identified by specialists who train or advise teachers as important in order to ensure the effective implementation of inclusive education in the classroom?

\section{Methods}

The qualitative study sample consisted of 15 SEN professionals who had to meet at least two of the following criteria in the field of inclusive education:

1) Experience in training teachers (e.g. professional development courses);

2) external advising experience (e.g. counsellor at state or municipality level);

3) internal advising experience at school level.

Data were collected with semi-structured interviews, which were fully transcribed. The data were analysed with qualitative inductive content analysis method based on the research questions.

\section{Major results and discussion}

\section{Interpreting the meaning of inclusive education}

The results of the survey showed that similarly to the study conducted by Häidkind and Oras (2016) among Estonian teachers and leaders of educational institutions, the meaning of inclusive education was interpreted differently by the professionals participating in this study. The possibility of a pupil with special educational needs to study in an ordinary school of residence was generally understood as inclusive education, but different ways of organising the learning was seen. For example, teaching both in a special class and in a regular class was brought up. However, some interviewees understood the meaning of inclusive education as simply access to education, including studying in special schools. There is a widespread 'multi-track' approach to inclusive education in the Estonian context, which implements inclusive education 
and accepts special provision in special schools. The results of the interview point out the need to harmonise the meaning of inclusive education among the specialists who train or advise teachers.

\section{Factors of effective implementation of inclusive education}

The effective implementation of inclusive education in the classroom in Estonian context was seen as similar to Schuelka's (2018) approach: a complex issue that depends on the interaction of many different factors, such as school management, available resources and allocation, and trained teachers. Based on the results of the interview, one of the crucial components was the need for more training for teachers and other specialists who support teachers. Although teachers' knowledge about inclusive education and its contemporary trends was highlighted, special pedagogical competences of teachers is still a priority. Even though several studies emphasise the need for teachers to be able to apply a variety of proven strategies in inclusive classrooms, such as peer-assisted learning (Saloviita, 2018; European Agency, 2003), the interviewees in this study referred less to inclusive classroom strategies. In addition to the training needs, similarly to the study by Engelbrecht et al. (2017), the importance of the necessary resources was emphasised, including the availability of human resources. Concerning the resources for the learning environment, the availability of necessary facilities, smaller number of students in the classroom and the availability of teaching and learning materials were highlighted. Reference was also made to the teachers' time resources and the need to reduce the workload on teachers who teach in inclusive classrooms. Other prerequisites for effective implementation of inclusive education were the need for supporting and motivating teachers which is also mentioned in Kaur et al. (2015), and the importance of cooperation between different stakeholders which has been highlighted by Engelbrecht et al. (2017).

In conclusion, in order to improve inclusive teacher education in the Estonian context, first and foremost it is necessary to focus on a common understanding of the meaning of inclusive education and effective practices among teacher educators and other professionals who advise teachers, which in turn requires greater research-based collaboration between educators and universities. Another major challenge is the development of pre-service and in-service teacher training courses based on the needs of teachers and sciencebased research.

Keywords: inclusive education, meaning, factors for implementation, effective teaching methods 